www. revis t a d y o. com

\title{
A study on impact of the UN Decade of Education for Sustainable Deve- lopment on Industrial Engineering Education
}

Estudio del impacto del Decenio de las Naciones Unidas de la Educación para el Desarrollo Sostenible sobre la Educación en Ingeniería Industrial

Ciliana Colombo ${ }^{1}$, Anabela Alves $^{2}$, Francisco Moreira² y Natascha van Hattum-Janssen ${ }^{3}$

${ }^{1}$ Dpto. Production Engineering. Universidade Federal do Rio Grande do Norte. Rio Grande do Norte. Brazil.

${ }^{2}$ Dpto. Production and Systems. University of Minho. Guimarães. Portugal.

${ }^{3}$ Saxion University of Applied Sciences, Enschede, The Netherlands

cilianacolombo@gmail.com; anabela@dps.uminho.pt, fmoreira@dps.uminho.pt, nataschavanhattum@gmail.com

Fecha de recepción: 25-10-2014

Fecha de aceptación: 28-05-2015

\begin{abstract}
The United Nations Decade of Education for Sustainable Development, UN/DESD 2005-2014, is reaching its term. The decade was launched with an international footage with the main objective of providing general guidelines that could be readily adapted to a broad audience and diverse learning contexts, so as to further disseminate the concept and rationale of Sustainable Development. Following a bibliographical and documentary review of key journals and conference proceedings, akin to the field of Engineering Education, we present some key figures and trends regarding the introduction of sustainability aspects into engineering degrees within the last 15 years, and review key dissimilarities among the distinct approaches identified. The study reveals a growing number of publications in the field, but a rather small number related to Industrial Engineering Education. Another result relates to the fact that the review rarely found papers that make a reference to the UN/DESD, which surprisingly seems to indicate a poor awareness of such global program.
\end{abstract}

Keywords: Education for Sustainable Development, Sustainable Development, Engineering Education, Industrial Engineering.

Resumen: El Decenio de las Naciones Unidas de la Educación para el Desarrollo Sostenible, UN/DEDS 2005-2014, está llegando a su fin. La década se inició con amplitud internacional, con el objetivo de proporcionar una orientación general para difundir el concepto y fundamentos del desarrollo sostenible. El artículo presenta una revisión bibliográfica en revistas y actas de congresos de la Educación en Ingeniería en los últimos 15 años, observando la introducción de cuestiones de sostenibilidad en los cursos de ingeniería, en particular de la Ingeniería de Organización. El estudio revela un creciente número de publicaciones en el campo, pero, un número muy pequeño se refiere a DEDS, lo que puede indicar que este programa no fue globalmente reconocido y desarrollado.

Palabras clave: Educación para el Desarrollo Sostenible, Desarrollo Sostenible, Educación en Ingeniería, Ingeniería Industrial.

\section{Introduction}

Engineers have an important role in society and nature. Their activity has a direct impact on people's lives and nature; however, most people, including engineers, are not sufficiently aware of this impact. Back in 2010, UNESCO launched a report about engineering and its large contribution to development (UNESCO, 2010) in order to improve global awareness of its role in society. But the contribution of engineers to society and their role in developing the world only makes sense if they take into account ecological, social and economic aspects i.e. make a genuine contribution to a sustainable future. Bearing in mind that education represents a key opportunity to develop awareness and knowledge on this field, UNESCO has launched the Decade of Education for Sustainable Development (DESD) (UNESCO, 2005) to promote, in a global way, guidelines and advice, that enables institutional partners and individuals to develop their own contribution for education for sustainable development based on their own contexts. 
This paper reviews the relevant publications on Engineering Education (EE) with emphasis on Sustainability and the UN/DESD objectives. The study is focused on Industrial Engineering Education (IEE) since the authors are teachers in this disciplinary area. The study gears from publications on EE on journals and on-line conference proceedings over a time frame of 15 years [2000-2014]. It also seeks to research how the requirements of the DESD are included in engineering curriculum. Furthermore the study emphasizes the learning methodology and the eventual link with the DESD.

\section{Decade of Education for Sustainable Development}

Interest for Education for Sustainable Development (ESD) arose when Sustainable Development was established as a global goal by the 1987 General Assembly of United Nations (United Nations, 1987). Five years later, in the Earth Summit of Rio de Janeiro 1992, ESD started to take shape in chapter 36 "Promoting Education, Public Awareness and Training" of Agenda 21 (United Nations, 1992). The need for this Education was emphasized in Rio+10 (United Nations, 2002) and Rio+20 (United Nations 2012) conferences. This last conference resulted in an important resolution, Resolution $n^{\circ} 57 / 254$, proclaiming the Decade of Education for Sustainable Development (DESD) - 20052014. UNESCO was nominated as responsible for the elaboration of an international implementation plan to achieve DESD objectives. The main idea of DESD is to create a set of partnerships that seeks to bring together a wide range of interests and concerns and to be an instrument of mobilization and information dissemination. It also intends to build a network of responsibilities in which governments, international organizations, civil society, private sector and local communities around the world demonstrate their practical commitment to learn how to live sustainably.

The global objective of DESD is to integrate the inherent values of SD in all aspects of learning to foster behavioral changes that promote sustainable and just societies. ESD reflects a concern for education of high quality and presents the following characteristics: interdisciplinary and holistic; values-driven; development of critical thinking and problem solving competences; mixed methods; participatory decision-making; local and real-life applicability.

DESD demands a reevaluation of the educational policy, in order to reorient the education, starting from nursery school right up to tertiary education, including adult lifelong learning focused on knowledge, competences, perspectives and values relating to sustainability
(UNESCO, 2005). This implies a review of educational approaches, objectives and contents of curricula in order to develop an interdisciplinary understanding of sustainability in various dimensions (social, economic, environmental, cultural,...). Furthermore, it is fundamental to review of learning methodologies to promote the competences for lifelong learning such as: critical and creative thinking, oral and written communication, collaboration and cooperation, conflict management, decision making, problem solving and project management, ICT appropriate use and practical citizenship. According to UNESCO, the educational system needs to be reformed towards this kind of learning, while incorporating best practices (UNESCO, 2005).

\section{Research method}

The research method used in this paper is based on a literature review of publications in a 15-year period [2000-2014], which encompasses a pre DESD stage and the DESD itself, although the theme of sustainability within engineering education dates back to the last decades of the last century. The data relating the year 2014 is partially completed only, since the study was conducted on the first quarter of 2014. Renown journals in Engineering Education were selected: the Journal of Engineering Education (JEE), the Brazilian Journal of Engineering Education (published in Portuguese - Revista de Ensino de Engenharia (RevEE)), the European Journal of Engineering Education (EJEE), the International Journal of Sustainability in Higher Education (IJSHE) and the Journal of Professional Issues in Engineering Education and Practice (JPIEEP). Two representative conference proceedings with on-line proceedings were also selected: the American Society of Engineering Education (ASEE), and the Brazilian Conference of Engineering Education (Congresso Brasileiro de Ensino de Engenharia COBENGE). Journals that are not specifically targeted on Engineering Education were excluded from the study, even the ones that are targeted on sustainability progress, e.g. Journal of Cleaner production; Journal of Environmental Management.

The search criteria included the title only, and the key word "Sustainab" for all the journals. This search grasps all papers entitled "sustainability"; "sustainable"; "sustainabilities"; "unsustainable". Different criteria were used for the ASEE conferences since the word "sustainability" in the ASEE conferences originates more than 1000 occurrences, so, only papers of the sessions with "sustainability" word were selected (75 papers were analysed). In the case of the Brazilian papers, the keyword used (in Portuguese), also in the title, was: "Sustent"". After identification of the title with 
keywords, the relevance of the paper was verified in the abstract and the paper was selected for analysis. The papers were then checked for relevance by scrutinizing the contents of the abstract, and selected for further analysis. A total of 170 papers were reviewed and analyzed with respect to program or courses where sustainability aspects were addressed, learning methodology were discussed and how such issues were tackled, and if DESD was referred.

\section{Figures and trends of sustainability in engineering degrees}

This section presents some figures and trends about sustainability programs and courses in engineering degrees. Before the UN declaration of the DESD some universities were already concerned with sustainability. In reality, one can track the need to bring this issue to the global arena back to 1972, with the Stockholm declaration, and the following UN summits on Human Environment, culminating with the publication of the Brundtland Report (1987), that appealed to the integration of sustainability concepts into the engineering curricula. As depicted in Figure 1a, the study shows a clear trend towards an increased number of publications in sustainability issues within the context of Engineering Education over the last 10 years. One can observe that in the first period [2000-2004] the total number of papers was lower than a third of those published on the second period [2005-2009], while the last period [2010-2014] registered a smaller increment only. The evolution of publications about sustainability programs can be seen in Figure 1b, in three periods of five years.

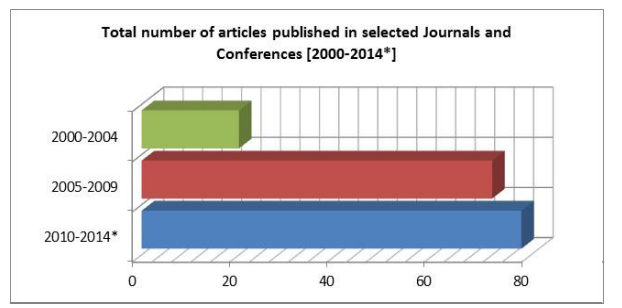

a)

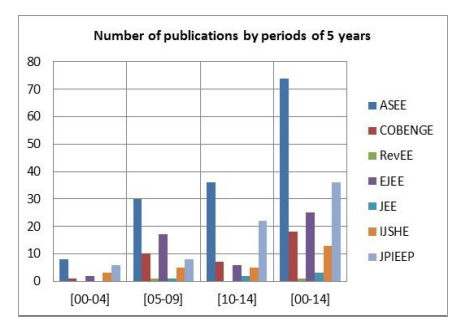

b)

Fig. 1 Total number of papers in [2000-2014*]: a) By 5 years period; b) By conference/journal $\left(^{*}\right) 2014$ is partially completed only.
As expected, the last period knows a total increase, although, surprisingly, EJEE shows a decrease. Most publications were about Civil, Chemical or Environmental Engineering (for example, in 74 ASEE papers more than $50 \%$ were in these disciplinary areas). Others programs were less represented, for example, only 13 papers (17\%) in ASEE papers were about Industrial Engineering.

\subsection{The first period: $\mathbf{2 0 0 0 - 2 0 0 4}$}

The first period of the study includes publications published between 2000 and 2004. This period precedes the formal launch of the United Nations DESD, which took place in 2005. The numbers for the selected journals and conferences are depicted in Figure 2. Here, one can observe that the scientific publications that relate Engineering Education to Sustainability were intermittent over consecutive years and the subject was not common. These numbers also indicate that some universities started preparing engineers for sustainable development. This figure shows that ASEE published more papers than the others, starting in 2002. In the years 2000 and 2001, only IJSHE and JPIEEP were publishing papers.

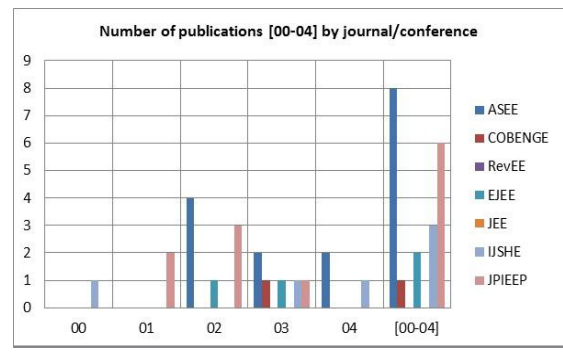

Fig. 2 Publications about sustainability programs and courses in first period: [00-04]

In ASEE conference proceedings most course objectives of newly developed courses, were about exposing the freshman engineering students to green engineering principles and environmental Life Cycle Assessment. These courses were based on project and case studies, on the use of in-class examples, cooperative learning exercises, homework assignments, contests, social projects through NGO (such as Engineers without Borders - EWB) or projects supported by governmental agencies (such as the U. S. Environmental Protection Agency - EPA). Other cases reported were from universities that promoted initiatives and sustainable engineering programs for undergraduate/graduate levels. Some programs focused on Chemical Engineering and Civil Engineering, but most publications referred to the transversal character of the courses proposals to all engineering programs. One such initiative implied the collaboration with industry through a ConsEnSus 
Program (Lueking et al., 2003) described by the authors as case studies that brought together practitioners and students to discuss real-world sustainability problems. In this period, COBENGE published only one paper (in 2003) about sustainability in engineering programs. This paper showed the importance of the systemic approach in engineering programs to attain SD. It also presented some relevant topics and courses akin to the theme of sustainability.

Only two papers were published by EJEE during this period. These were essentially targeted on (1) uncovering strategies that individuals were using to take sustainability issues into particular subject lectures in engineering education, and (2) presenting a case study on sustainability know-how of Chemical Engineering students. Both studies were intended to assess the need for improvements on sustainability learning into the engineering curriculum structure.

\subsection{The second and the third period}

The second period [2005-2009] reports to the first period of the international implementation plan of DESD. This period was richer in publications on sustainability in ASEE conferences, with a peak number of sessions on "Sustainability" in 2008 (7 sessions). One can also observe a growing number of publications over this period, which was expected (Figure $3 a)$. The third period [2010-2014] is even richer than the previous one. These figures do not include yet the conference papers held in 2014 (Figure 3b).

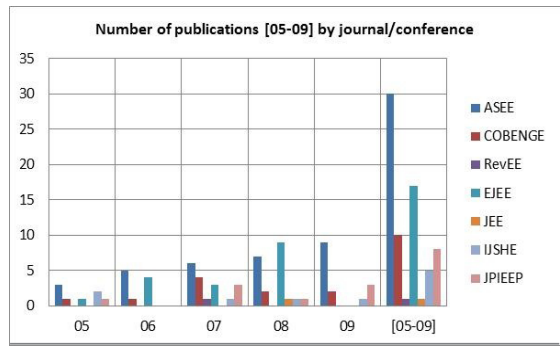

a)

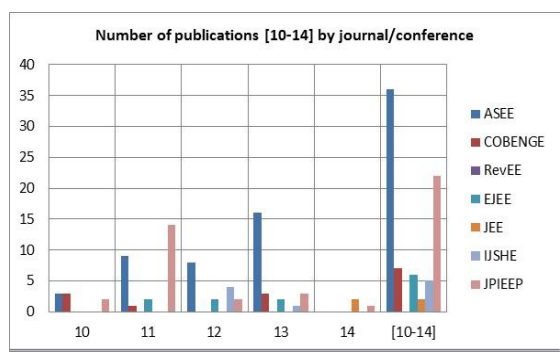

b)

Fig. 3 Number of publications on the: a) second period [05-09]; and b) third period [10-14]
The EWB activities, framed as a service-oriented learning, is a learning methodology that seems to hold at least some level of success (Bosscher et al. 2005; Baldwin 2006; Pines \& Gallant 2006). Another learning methodology reported was the use of videos (Zhou, 2005). These were brought as a way to overcome the limitation of lack of field trip opportunities and to help bring real-world applications to the classroom. Research Experiences for Undergraduates (REU) site was promoted for Pollution Prevention and Sustainability (Jahan et al. 2005). Collaborative efforts between the College of Engineering and the College of Liberal Arts and Sciences were conducted in these REU. These experiences integrated social building skills, such as community outreach seminars, workshops, social picnics, field trips and communication strengthening exercises. Also, a common factor in many programs reported in ASEE papers involved multidisciplinary teams of faculty members and teams of students, with an emphasis on active learning through "hands-on activities", internships summers, international and research experiences and real world applications. In this period, COBENGE papers dealt with all engineering degrees, addressing the need for reassessment of programs to introduce the theme of sustainability. Also, alike ASEE papers, it addresses the need to integrate the new paradigm in engineering, preparing the students and faculty to work in interdisciplinary and inter-institutional contexts. Service-learning projects also are used to acquire SD knowledge ability. In RevEE only one paper was published (in 2007), mainly addressing the same concerns of COBENGE papers and the need to debate the issues of sustainability, involving all stakeholders, in field classes and workshops oriented to the community. The JEE, IJSHE and JPIEEP journals, reported similar approaches.

There is a clear trend towards more yearly publications on sustainability issues in the EJEE over this period. From these papers, the three-tier approach for teaching sustainability, that encompassed dedicated lectures, case studies and integration of sustainability into the Chemical Engineering curriculum, is emphasized (Azapagic et al., 2005). Another approach for the same engineering degree and Materials Sciences Engineering was supported with lectures and project work, which encapsulated the development of technical and soft skills, namely, entrepreneurship (Bonnet et al., 2006). In another paper, the idea of the need for sustainable technological development that could be accrued with the redesign of courses and design work, a compulsory training module and a special graduation certificate on Sustainable Development (Mulder, 2006), was highlighted. The following learning strategies were considered: PBL based studio oriented design, workshop based exercises and long seminars involving 
students and SME professionals. The use of project approaches in sustainability engineering education, while acquiring technical and transversal skills was also reported in some papers.

The novelty of ASEE publications in the last period [2010-2014] was the preparation of the academics for teaching sustainability issues (Hoffmann et al., 2010). A concern shown in this period was the evaluation of sustainability programs (McCormick et al., 2010). A report on Benchmarking Sustainable Engineering Education (BSEE) was launched to identify accredited engineering programs at U.S. institutions (Allen et al., 2008). This was intended at verifying if the programs are currently incorporating sustainability concepts into engineering curricula. Educational games appears as a learning methodology to teach sustainability ethics (Spierre et al., 2012). COBENGE papers in this period bring a new concern: the increase of a holistic and interdisciplinary vision needed to integrate sustainability aspects in engineers' education and the role of the teachers in this vision. Most of these papers were about engineering degrees in general.

The journal papers also presented some case studies and practices adopted by some universities to achieve sustainability aspects in their curricula. The extraordinary increase of JPIEEP papers in 2011 is due to a special issue on Sustainability in Civil and Environmental Engineering. RevEE did not publish and JEE two papers are just of this year. EJEE knew a decrease of papers in this period (6) over the previous period. An analysis of these issues revealed concerns relating sustainability education in engineering and industrial design, namely on the specific topic of materials scarcity, the need to scrutinize curricular content, and introduction of specific courses on Sustainability.

\section{Conclusions}

A 15-year literature review encompassing a number of selected journals and conferences on Engineering Education was conducted. This targeted on reviewing previous studies on the Engineering Education for Sustainability issue, which was brought to discussion by UN and academics starting on the early 1970s, reemphasized with the Brundtland Report in 1987, and culminating with the launch of the UN/DESD in 2005. This study reviewed 170 papers across two conference proceedings, representing $54 \%$ of the total, and five journals, representing the remaining $46 \%$. The utmost part was published during the DESD itself (88\%), and about $12 \%$ only published in the half-decade period that preceded it. Most papers exposed the need to incorporate Sustainability into engineering learning and practice, but the approaches suggested to fit it in engineering education might encompass, among others: (1) reform of engineering curricula; (2) specific programs and courses on sustainability; (3) cross-disciplinary courses offered jointly with non-engineering departments. A number of learning approaches are suggested to achieve that, such as active learning, project-based learning, interdisciplinary learning, collaborative learning, service-oriented learning, use of case studies, workshops and seminars involving the industry, hands-on and field activities.

A very small number of the papers reviewed specifically address Industrial Engineering Education. Many of them targeted engineering in general, but Civil, Environmental and Chemical Engineering were more frequently found. Surprisingly, a poor number of papers make a link with UN/DESD, this seems rather peculiar since UN works are reportedly consistent for many decades, and the DESD holds a global framework.

\section{References}

ALLEN D, ALLENBY B, BRIDGES $M$ et al (2008). Benchmarking Sustainability Engineering Education: Final Report: EPA Grant X3-83235101-0.

AZAPAGIC A, PERDAN S \& SHALLCROSS D (2005). "How much do engineering students know about sustainable development? The findings of an international survey and possible implications for the engineering curriculum". European Journal of Engineering Education, 30(1), pp.1-19. Available at: http://www.tandfonline.com/doi/abs/10.1080/03043 790512331313804 [Accessed March 20, 2014].

BALDWIN J (2006). "Service Learning Project in Brazil : From Concept to Reality". In Proceedings of the 2006 American Society for Engineering Education Annual Conference \& Exposition. pp. 2006-1369.

BONNET H, QUIST J, HOOWATER D et al (2006). “ Teaching sustainable entrepreneurship to engineering students: the case of Delft University of Technology". European Journal of Engineering Education, 31(2), pp.155-167. Available at: http://www.tandfonline.com/doi/abs/10.1080/03043790600566979 [Accessed March 20, 2014].

BOSSCHER PJ, RUSSELL JS \& STOUFFER WB (2005). "The Sustainable Classroom: Teaching Sustainability to Tomorrow 's Engineers)". In Proceedings of the 2005 American Society for Engineering Education Annual Conference \& Exposition. 
HOFFMANN S, Hua I, BLATCHLEY E et al (2010). "Integrating Sustainability into Courses Across the Engineering Curriculum : A Faculty Workshop Mode"l. In Proceedings of the 2010 American Society for Engineering Education Annual Conference \& Exposition. p. AC 2010-1802.

JAHAN K, SAVELSKI M, ORLINS J et al (2005). "Undergraduate Research in Pollution Prevention and Sustainability". In Proceedings of the 2005 American Society for Engineering Education Annual Conference \& Exposition.

LUEKING AD, ROSS DA \& WEBER WJ (2003). "Environmental sustainability education at the university of Michigan : collaboration with industry to provide experiential learning opportunities". In Proceedings of the 2003 American Society for Engineering Education Annual Conference \& Exposition. p. Session -3551 .

McCORMICK M, LAWYER K, BERLIN M et al (2010). "Evaluation of Sustainable Engineering Education via Service Learning and Community Service Efforts". In Proceedings of the 2010 American Society for Engineering Education Annual Conference \& Exposition. p. AC 2010-1102.

MULDER KF (2006). "Engineering curricula in sustainable development. An evaluation of changes at Delft University of Technology". European Journal of Engineering Education, 31(2), pp.133-144. Available at: http://www.tandfonline.com/doi/ abs/10.1080/03043790600566912 [Accessed March 20, 2014].

PINES D \& GALLANT B (2006). "Providing Engineering Students a Global Perspective through a Project for Developing Communities - Lessons Learned at the University of". In Proceedings of the 2006 American Society for Engineering Education Annual Conference \& Exposition. pp. 2006-1188.
SPIERRE S, MARTIN EA, SADOWSKI J et al (2012). "An Experiential Pedagogy for Sustainability Ethics". In Proceedings of the 2012 American Society for Engineering Education Annual Conference \& Exposition. p. AC 2012-3207.

UNESCO (2010). Engineering: Issues, Challenges and Opportunities for Development, UNESCO.

UNESCO (2005). United Nations Decade of Education for Sustainable development 2005-2014- Draft International Implementation scheme, UNESCO.

UNITED NATIONS (1987). Our Common Future: Report of the World Comission on Environment and Development

UNITED NATIONS (2012). Report of the United Nations Conference on Sustainable Development

UNITED NATIONS (2002). Report of the World Summit on Sustainable Development, Johannesburg, South Africa.

UNITED NATIONS (1992). United Nations Conference on Environment \& Development: Agenda 21. In United Nations Conference on Environment \& Development:

ZHOU J (2005). "Effective Use of Videos to Enhance the Teaching and Learning of Environmental Engineering". In Proceedings of the 2005 American Society for Engineering Education Annual Conference \& Exposition. 